\title{
Potato diseases and measures to control them in the conditions of the middle Urals
}

\author{
M.Yu. Karpukhin*, and F. Keita \\ Ural State Agrarian University, 620075 Ekaterinburg, Russia
}

\begin{abstract}
The objective of this research is to study the manifestation of the main diseases of potato during the vegetation period of plants and storage of tubers. The research was carried out on the experimental field of the educational and experimental farm "Uralets" of the Ural State Agrarian University (USAU), the village "Studencheskiy", during 2016-2018 in the climatic zone of the Middle Urals. According to the results of the research carried out, it was found that with the use of the optimal feeding area and the fungicide shirlan in the fight against pathogens, it was possible to obtain a yield of $36.6 \mathrm{t} / \mathrm{ha}$, which is $31.1 \%$ higher than the control (factor A). At the same time, the cost price amounted to 4,446 rubles/ton, profit 269,172 rubles/ha, and profitability $-165.43 \%$.
\end{abstract}

\section{Introduction}

Potato is one of the main crops. In Russia it is rightly called "the second bread". It is widely used both as a technical and as a feed crop. Increase of potato production depends mainly on an increase in yields, the introduction of high-yielding varieties into production, an increase in soil fertility, the introduction of advanced mechanized technology for the cultivation of this crop, and an improvement in seed production. This complex of measures should include the protection of potato from diseases, pests and weeds [11].

In 2018, world potato production amounted to 368.2 million tons on an area of 18.5 million hectares [16].

Russia occupies one of the leading places in the world in terms of the gross harvest of potato tubers ( $10 \%$ of the world volume), but in terms of productivity it is significantly inferior to all the leading potato growing countries of the world [8].

Harvest of potato in Russia in 2016 amounted to 31.1 million tons, which is $15.9 \%$ more than the average for the last five years. In 2015, more was harvested: 33.6 million tons of potato. In 2017, the gross harvest of potato in farms of all categories amounted to 29.6 million tons, which is $5 \%$ less than the gross harvest of $2016[7,13]$.

The gross harvest of potato in the Sverdlovsk region in 2018 amounted to 218.2 thousand tons excluding the population (the fact of 2017 - 250.7 thousand tons) with an average yield of $178.3 \mathrm{c} / \mathrm{ha}[6]$.

One of the reasons for the low yields of potato is the widespread occurrence of diseases, pests and weeds. Tops and tubers rich in carbohydrates and water provide a favorable

\footnotetext{
* Corresponding author: mkarpukhin@yandex.ru
} 
environment for the development of a wide variety of pathogens and pests. An important feature of potato is that, due to vegetative reproduction, most of the diseases affecting it are transmitted through seed tubers, which are the primary source of infection for subsequent infection of plantings. Potato can be affected by diseases at all stages of the life cycle: before germination, during the vegetation period and during storage. Many pathogens are also capable of accumulating and persisting for a long time in the soil [1].

Worldwide loss of potato crop is approximately $32 \%$ from diseases, $10 \%$ from pests, $6 \%$ from weeds, against $15 \%, 3 \%$ and $4 \%$, respectively, in the Great Britain [15].

According to the United Nations Commission on Agriculture and Food (FAO), the global loss of potato crop from diseases annually in monetary terms amounts to 88.9 million tons, amounting to 3.4 billion dollars or $11.6 \%$ of the total gross harvest, which is 2 times higher than losses in cereals, vegetables and sugar beets $[10,11]$.

In Russia, according to long-term data, the annual shortage of potato harvest from diseases and pests during the vegetation period in a number of regions, depending on the variety, ranges from 23 to $29 \%$, and in some years exceeds $50 \%$. Potato losses during storage are also significant. As a result of the development of wet and dry rot, they often reach $30-40 \%[3,4,5,12]$.

In the Urals, potato is affected by more than 25 types of various diseases, of which late blight, macrosporosis (brown spot), Rhizoctonia (black scab), common scab, phoma rot, bacterial diseases - black leg and ring rot, viral diseases are dangerous [9].

In the Sverdlovsk region, potato is annually affected by diseases to one degree or another. In some years, with a combination of unfavorable conditions for plant development, diseases sharply reduce the potato yield. Despite this, there are not enough measures taken to prevent the emergence of diseases and destroy them.

From the practice of potato growing in the Urals, there are examples of high yields of potato obtained as a result of the use of a complex of agro-technical measures [14].

The purpose of this research is to study the influence of the feeding area of Gala potato, the use of fungicides on the yield and quality of tubers in the conditions of the Middle Urals

The objective of this research is to study the manifestation of the main diseases of potato during the vegetation period of plants and storage of tubers.

\section{Materials and Methods}

The research was carried out on the experimental field of the educational and experimental farm "Uralets" of the Ural State Agrarian University (USAU), the village "Studencheskiy", for three years (2016-2018) in the climatic zone of the Middle Urals. For the object of research in the experiment was taken a variety of potato for table use, medium early, highyielding Gala, bred by German breeders, originator Norika (Germany). In the experiment, two fungicides were studied: shirlan and infinito.

The soil of the experimental site is podzolized chernozem, heavy loamy in granulometric composition with a humus content of $4.5 \%$, the reaction of the soil environment is weakly acidic, the availability of mobile phosphorus is low, exchangeable potassium is medium. The arable layer is $25 \mathrm{~cm}$ deep, and the availability of available forms $\mathrm{N}, \mathrm{P}$ and $\mathrm{K}$ is very low. Agrochemical parameters of podzolized chernozem soil: saline $\mathrm{pH}-5.4 ; \mathrm{N}-185.9 \mathrm{mg} / \mathrm{kg}$ of soil; $\mathrm{P}_{2} \mathrm{O}_{5}-238.9 \mathrm{mg} / \mathrm{kg} ; \mathrm{K}_{2} \mathrm{O}-268.5 \mathrm{mg} / \mathrm{kg}$.

The experiment (two-factor) consists of 15 variants and 4 replications. The area of one plot is $20 \mathrm{~m}^{2}$ (width $=2.5 \mathrm{~m}$ and length $=8 \mathrm{~m}$ ), a total of 60 test plots, the total area of the experiment is $1200 \mathrm{~m}^{2}$. The placement of plots in the experiment is systematic. The row spacing is $70 \mathrm{~cm}$, and the distance between plants in a row is from 20 to $40 \mathrm{~cm}$. The soil and climatic conditions of the Middle Urals are favorable for potato cultivation. 
In the Middle Urals, a new high-yielding, medium-early variety Gala has recently been spreading, characterized by relative resistance to diseases and good tuber preservation in winter. The cultivation technology of the variety under these conditions has not been studied; therefore, the study of the methods of cultivation of this variety is justified and actually.

The Gala variety has the following characteristics: The period from planting to harvest is $70-80$ days. Harvest $21.6-26.3 \mathrm{t} / \mathrm{ha}$, maximum $39.0 \mathrm{t} / \mathrm{ha}$. The tuber is oblong-oval with small eyes. The peel is smooth, yellow. The pulp is dark yellow. The mass of commercial tubers is $71-122 \mathrm{~g}$. The number of tubers in a bush is on average 10-16 pieces (up to 25).Potential yield of Gala- $60.0 \mathrm{t} / \mathrm{ha}$. Starch content $10.2-13.2 \%$. The taste is very good. Marketability - 71-94\% and keeping quality about $89 \%$. The variety is resistant to the causative agent of potato cancer (Synchytrium endobioticum) and the golden potato cyst nematode (Globodera rostochiensis).Variety is susceptible to late blight (Phytophthora infestans) in tops and tubers [2].

New fungicides, such as contact action shirlan and systemic infinito, have been selected for research, which are now becoming widespread.

\section{Results and Discussion}

The research results showed that the species composition of pathogens after treatment remained the same, but the percentage of distribution and the degree of damage changed. The percentage of late blight and alternaria spread is shown in Table 1.

Table 1. Distribution (\%) of diseases on potato plants depending on the feeding area and the use of fungicides, 2016-2018

\begin{tabular}{|c|c|c|c|c|c|c|}
\hline $\begin{array}{c}\text { Feeding area, } \\
\mathrm{cm}^{2}\end{array}$ & \multicolumn{3}{|c|}{ Late blight (Phytophthora infestans) } & \multicolumn{3}{|c|}{ Alternaria (Alternaria solani) } \\
\cline { 2 - 7 } & control & shirlan & infinito & control & shirlan & infinito \\
\hline 1400 & 17,3 & 5,9 & 6,8 & 15,6 & 5,1 & 6,8 \\
\hline 1750 & 17,8 & 5,7 & 7,8 & 13,8 & 4,7 & 6,8 \\
\hline $2100(\mathrm{c})$ & 20,4 & 5,5 & 7,7 & 12,0 & 4,4 & 6,6 \\
\hline 2450 & 18,6 & 5,6 & 6,2 & 10,6 & 4,2 & 6,2 \\
\hline 2800 & 17,1 & 4,6 & 5,6 & 10,0 & 3,1 & 4,2 \\
\hline $\mathrm{r}=$ & 0,04 & $-0,84$ & $-0,66$ & $-0,98$ & $-0,95$ & $-0,83$ \\
\hline
\end{tabular}

From the data in the table 1, we observe that in the control variant, the spread of late blight (Phytophthora infestans) was 17.1-20.4\% and did not depend much on the size of the feeding area $(r=0.04)$.

After treatment with shirlan, the spread of late blight decreased three times, regardless of the feeding area $(\mathrm{r}=-0.84)$. The use of the fungicide infinito reduced the spread of the disease by 2.6-3.0 times. Here the influence of the area of plant nutrition was minimal.

Similar patterns were established in the experiment on the distribution of Alternaria solani. In the control variant, the susceptibility of plants to Alternaria was $10.0-15.6 \%$ (at $r$ $=-0.98$ ), and when treated with Shirlan, the percentage of plant damage was within 3.1$5.1 \%$ (at $r=-0.95)$. In variants with infinite treatment, the percentage of plants affected by Alternaria was in the range of $4.2-6.8 \%$ (at $r=-0.83$ ).

It is noted that the weather conditions during the years of research were favorable and contributed to the emergence, spread and development of Alternaria on potato plantings. Basically, the disease manifested itself in the budding phase and continued to grow in subsequent phases of plant development until the foliage died.

The severity to potato plants by late blight during the vegetation period, depending on the feeding area and the use of fungicides, is presented in Table 2. 
Table 2. The severity to potato plants by late blight (Phytophthora infestans) depending on the feeding area and fungicides, 2016-2018

\begin{tabular}{|c|c|c|c|c|c|c|}
\hline $\begin{array}{c}\text { Feeding area, } \\
\mathrm{cm}^{2}\end{array}$ & \multicolumn{2}{|c|}{ Control } & \multicolumn{2}{c|}{ Shirlan } & \multicolumn{2}{c|}{ Infinito } \\
\cline { 2 - 7 } & $\begin{array}{c}\text { average } \\
\text { score }\end{array}$ & $\begin{array}{c}\text { severity, } \\
\%\end{array}$ & $\begin{array}{c}\text { average } \\
\text { score }\end{array}$ & $\begin{array}{c}\text { severity, } \\
\%\end{array}$ & $\begin{array}{c}\text { average } \\
\text { score }\end{array}$ & $\begin{array}{c}\text { severity, } \\
\%\end{array}$ \\
\hline 1400 & 1,19 & 29,7 & 0,17 & 4,2 & 0,22 & 5,6 \\
\hline 1750 & 1,11 & 27,9 & 0,16 & 4,0 & 0,22 & 5,6 \\
\hline $2100(\mathrm{c})$ & 1,04 & 26,2 & 0,14 & 3,6 & 0,22 & 5,5 \\
\hline 2450 & 0,96 & 24,0 & 0,14 & 3,5 & 0,17 & 4,3 \\
\hline 2800 & 0,77 & 19,2 & 0,12 & 3,1 & 0,15 & 3,8 \\
\hline $\mathrm{r}=$ & $-0,97$ & $-0,97$ & $-0,99$ & $-0,99$ & $-0,97$ & $-0,97$ \\
\hline
\end{tabular}

From the data in the table 2 it can be seen that in the control variant, the severity to plants by late blight changed from 19.2 to $29.7 \%$, with an average score from 0.77 to 1.19 . In the variant with treatment with shirlan, the severity of plant by late blight varied from 3.1 to $4.2 \%$, with an average score from 0.12 to 0.17 . When treated with the fungicide infinito, the severity of plant by late blight ranged from 3.8 to $5.6 \%$, with an average score from 0.15 to 0.22 .

It can be seen from the data presented that there is an inverse dependence of the severity in all variants of the experiment (control, treatment with shirlan and infinito) on the feeding area. In this case, the smaller the feeding area, the higher the severity $(r=-0.97$ in the control), $r=-0.99$ in the variants with treatment with shirlan and $r=-0.97$ when using the fungicide infinito.

During the harvesting period, potato tubers were affected by late blight, while the damage in the control variant was $4.08 \%$, when treated with shirlan $-1.0 \%$ and when treated with infinite $-1.52 \%$ (Table 3 ),

Table 3. Damage to potato tubers by late blight (Phytophthora infestans) during the harvesting period, depending on the feeding area and fungicides, 2016-2018.

\begin{tabular}{|c|c|c|c|c|c|c|c|c|c|}
\hline \multirow{2}{*}{$\begin{array}{c}\text { Landing } \\
\text { scheme, } \\
\mathrm{cm}\end{array}$} & \multicolumn{3}{|c|}{ Control } & \multicolumn{3}{|c|}{ Shirlan } & \multicolumn{3}{|c|}{ Infinito } \\
\hline & $\begin{array}{l}\text { Numbe } \\
\text { r of } \\
\text { tubers } \\
\text { per } \\
\text { plot, } \\
\text { pieces }\end{array}$ & $\begin{array}{l}\text { infecte } \\
\mathrm{d} \\
\text { tubers }\end{array}$ & $\%$ & $\begin{array}{c}\text { Number } \\
\text { of tubers } \\
\text { per plot, } \\
\text { pieces }\end{array}$ & $\begin{array}{l}\text { infecte } \\
\mathrm{d} \\
\text { tubers }\end{array}$ & $\%$ & $\begin{array}{c}\text { Numbe } \\
\text { r of } \\
\text { tubers } \\
\text { per } \\
\text { plot, } \\
\text { pieces }\end{array}$ & $\begin{array}{l}\text { infecte } \\
\mathrm{d} \\
\text { tubers }\end{array}$ & $\%$ \\
\hline $70 \times 20$ & 758 & 31 & 4,08 & 1220 & 9 & 0,73 & 921 & 12 & 1,30 \\
\hline $70 \times 25$ & 739 & 30 & 4,05 & 796 & 8 & 1,00 & 937 & 10 & 1,06 \\
\hline $\begin{array}{c}70 \times 30 \\
\text { (c) }\end{array}$ & 615 & 25 & 4,06 & 630 & 6 & 0,95 & 722 & 11 & 1,52 \\
\hline $70 \times 35$ & 760 & 19 & 2,50 & 668 & 5 & 0,74 & 608 & 9 & 1,48 \\
\hline $70 \times 40$ & 702 & 16 & 2,27 & 621 & 4 & 0,64 & 440 & 6 & 1,36 \\
\hline average & 715 & 24 & 3,35 & 787 & 6 & 0,76 & 726 & 10 & 1,37 \\
\hline $\mathrm{r}=$ & $-0,24$ & $-0,98$ & $-0,88$ & $-0,83$ & $-0,99$ & $-0,45$ & $-0,97$ & $-0,89$ & 0,47 \\
\hline
\end{tabular}

From the data in Table 3, we observe that in the control variant, a strong $(r=-0.88)$ inverse relationship was established, and during treatment with shirlan, an average $(r=-$ 0.45 ) inverse relationship between the percentage of damage and the feeding area, i.e. the larger the feeding area, the less the percentage of tuber damage by late blight. When treated 
with infinite, a direct average $(r=0.47)$ relationship between the feeding area and the percentage of tuber damage was noted.

During the storage period, potato tubers were affected by 6 types of pathogens: late blight (Phytophthora infestans), common scab (Streptomyces scabies), phomosis or button rot (Phoma exiqua), Rhizoctonia or black scab (Rhizoctonia solani), dry rot of potato (Fusarium solani) and ring rot (Corynebacterium sepedonicum).

The results of studies on the susceptibility of potato tubers to pathogens during storage are presented in Table 4.

Table 4. The incidence (\%) of potato tubers with diseases depending on the feeding area and the use of fungicides during the storage period, 2016-2018

\begin{tabular}{|c|c|c|c|c|c|c|c|c|c|}
\hline \multirow[t]{2}{*}{$\begin{array}{l}\text { Feeding } \\
\text { area, } \\
\mathrm{cm}^{2}\end{array}$} & \multicolumn{3}{|c|}{$\begin{array}{c}\text { Ring rot, Phomosis, Late } \\
\text { blight, Rhizoctonia, } \\
\text { Fusarium, } \\
\%\end{array}$} & \multicolumn{3}{|c|}{$\begin{array}{c}\text { Common scab, } \\
\%\end{array}$} & \multicolumn{3}{|c|}{$\begin{array}{c}\text { General susceptibility } \\
\%\end{array}$} \\
\hline & control & shirlan & infinito & control & shirlan & infinito & control & shirlan & infinito \\
\hline 1400 & 29,8 & 12,9 & 7,1 & 12,5 & 5,0 & 4,7 & 42,3 & 17,9 & 11,8 \\
\hline 1750 & 26,4 & 10,4 & 6,9 & 12,2 & 4,5 & 5,5 & 38,6 & 14,9 & 12,4 \\
\hline $\begin{array}{l}2100 \\
\text { (c) }\end{array}$ & 21,6 & 8,6 & 5,3 & 10,7 & 5,2 & 4,0 & 32,3 & 13,8 & 9,3 \\
\hline 2450 & 21,2 & 4,5 & 4,6 & 8,2 & 4,0 & 3,5 & 29,4 & 8,5 & 8,1 \\
\hline 2800 & 14,2 & 4,1 & 4,4 & 6,2 & 3,2 & 3,0 & 20,4 & 7,3 & 7,4 \\
\hline $\mathrm{r}=$ & $-0,97$ & $-0,98$ & $-0,96$ & $-0,97$ & $-0,80$ & $-0,86$ & $-0,98$ & $-0,98$ & $-0,93$ \\
\hline
\end{tabular}

From this table 4 , it can be seen that the plant density played a large role in the defeat of tubers by pathogens.

A direct inverse dependence of tuber attack on the feeding area was established: the smaller the feeding area, the greater the attack rate, while the dependence is strong - 0.9 -($0.98)$ in all variants, regardless of the type of fungicide. The highest percentage of tuber attack was the common scab fungus; in the control variant it reached 12.5 with dense planting and 6.2 with the sparse planting. The least of all tubers were affected by ring rot 3.7 - with dense planting and $1.0 \%$ with sparse planting. Of all the variants, the most effective was the contact action fungicide shirlan, under the influence of which the susceptibility to all diseases decreased by 2.5-3 times, depending on the feeding area.

\section{Conclusion}

Research conducted on the manifestation of the main diseases of potato during the vegetation period of plants and storage in the conditions of the Middle Urals allowed us to draw the following conclusions:

1.With the use of fungicides (shirlan and infinito), the species composition of pathogens did not change, but the percentage of distribution and the degree of damage decreased after the use of fungicides, due to which the yield increased.

Thus, the spread of late blight decreased from $20.4 \%$ in the control variant to $5.6 \%$ when using shirlan, and to $6.2 \%$ when using infinito. And the spread of Alternaria decreased from $12.0 \%$ in the control to $4.2 \%$ with Shirlan and to $6.2 \%$ with the use of Infinito. The severity of late blight also decreased from $26.2 \%$ in the control variant to $3.5 \%$ when using shirlan and to $4.3 \%$ when using infinito.

2. The use of the optimal feeding area and the fungicide shirlan in the fight against pathogens made it possible to obtain a yield of $36.6 \mathrm{t} / \mathrm{ha}$, which is $31.1 \%$ higher than the 
control (factor A). At the same time, the cost price amounted to 4,446 rubles/ton, profit 269,172 rubles/ha and profitability $-165.43 \%$.

\section{References}

1. B.V. Anisimov, G.L. Belov, Yu.A. Varitsev, S.N. Elansky, G.K. Zhuromsky et al., Potato protection against diseases, pests and weeds (M.: Potatoevod, 2009)

2. B.V. Anisimov, S.N. Elansky, V.N. Zeyruk, M.A. Kuznetsova et al., Potato varieties cultivated in Russia: Reference book (M.: Agrospas, 2013)

3. V.V. Vakulenko, Potatoes and Vegetables, 2, 34 (2016)

4. A.S. Volovik, V.M. Glez, A.I. Zamotaev, et al., Protection of potatoes from diseases, pests and weeds (Handbook, Moscow: Agropromizdat, 1989)

5. A.S. Volovik, V.M. Glez, V.I. Sedova, Guidelines for the use of pesticides in a biologized system of protection of potatoes from diseases and pests (M.: 2000)

6. A. Galitskikh, Niva Urala magazine special issue, 12-13 (2018) https: //uralniishoz.ru/uploadedFiles/files/2017/Spets_2018.pdf

7. L.N. Devyatkina, Bulletin of NGIEI, 5(84), 122-134 (2018)

8. V.V. Ivenin, A.V. Ivenin, A.P. Sakov, V.N. Bogomolov, A.A. Novosadov, Optimization of the Dutch system of soil cultivation under potatoes, (N. Novgorod: FGBOU VO Nizhegorodskaya State Agricultural Academy, 2017)

9. E.V. Kolobkov, Postnikov, N.A. Laptev, Plant protection in the Middle Urals: Scientific and practical recommendations (Yekaterinburg.: GNU Ural Research Institute of Agriculture of the Russian Agricultural Academy, 2012)

10. A.A. Kuzmichev, S.V. Maltsev, V.N. Zeyruk, Bulletin of RUDN University, series Agronomy and animal husbandry, 3, 29-37 (2014)

11. K.V. Popkova, Yu.I. Schneider, A.S. Volvik, V.A. Shmyglya, Potato diseases (M.: Kolos, 1980)

12. Z.Z. Salikhova, Z. Stashevsky, E.A. Gimaeva, Potato Protection, 1, 10-15 (2010)

13. O.A. Starovoitova, S.V. Zhevora, V.I. Starovoitov, E.V. Oves et al., Competitive technologies of seed production, production and storage of potatoes (M.: FGBNU "Rosinformagrotech", 2018)

14. E.P. Shumilenko, Potato diseases and measures to combat them (Sverdlovsk, 1956)

15. G.J. Jellis, R.E. Boulton, Damage and loss caused by potato diseases. In plant diseases: infection, damage and loss (Eds. Blackwell Scientific Publications Oxford, 1984)

16. FAOSTAT, 2018.World statistics Sept 2018. The United Nations selected series. https://unstats.un.org/unsd/mbs/data_files/t51.pdf. 